\title{
The Influence of Profitability on Firm Value using Capital Structure As The Mediator
}

\author{
Novi Mubyarto \\ UIN Sulthan Thaha Saifuddin Jambi, Indonesia,novimubyarto@uinjambi.ac.id
}

\begin{abstract}
The purpose of this research was to determine the direct and indirect effect of profitability on firm value using capital structure as a mediator. This involves using panel data from 44 companies listed on LQ45 as of 31st December 2015-2018 and analyzed using the path analysis method including Sobel Test and Bootstrapping technique. The results showed a positive and significant direct effect of profitability on firm value while the indirect effect using capital structure as a mediator between the two variables was found to be negative and significant. Moreover, the direct influence of capital structure on firm value was discovered to be negative and significant while the introduction of profitability variables in the relationship led to a positive and significant influence. Similarly, the direct effect of profitability on firm value using capital structure as the controlling variable was also found to be positive and significant.
\end{abstract}

Keywords: firm value, capital structure, profitability

\section{Pengaruh Profitabilitas Terhadap Nilai Perusahaan dengan Struktur Modal Sebagai Mediator}

\begin{abstract}
Abstrak
Tujuan dari penelitian ini adalah untuk mengkaji bagaimana pengaruh langsung profitabilitas terhadap nilai perusahaan, dan pengaruh tidak langsung melalui struktur modal sebagai mediator. Menggunakan data panel dari 44 perusahaan yang tercatat di LQ45 per tanggal 31 Desember selama periode 2015 sampai 2018. Metode analisis yang digunakan adalah metode analisis jalur (Path Analysis), dengan Teknik Sobel Test dan Bootsrapping. Hasil riset membuktikan bahwa terdapat pengaruh langsung yang positif dan signifikan antara profitabilitas terhadap nilai perusahaan. Namun, jika dilihat secara tidak langsung pengaruh profitabilitas terhadap nilai perusahaan melalui struktur modal sebagai mediator adalah negatif dan signifikan. Selanjutnya, pengaruh langsung profitabilitas terhadap struktur modal adalah negatif dan signifikan. Sementara ketika dikontrol oleh variabel profitabilitas, pengaruh struktur modal terhadap nilai perusahaan positif dan signifikan. Begitu pula dengan pengaruh langsung profitabilitas terhadap nilai perusahaan dengan mengontrol variabel struktur modal juga positif dan signifikan.
\end{abstract}

Kata kunci: nilai perusahaan, struktur modal, profitabilitas

\section{INTRODUCTION}

The continuous growth of economic and social conditions is changing the attitudes, behaviors, and mindset of communities from being a saving to an investing society and this is evident in the increasing public interest in capital market investment in Indonesia. The Indonesia Stock Exchange (IDX) reported that the number of single investor identification (SID) in Indonesian capital market had reached 1.68 million SID as at January 2019 (Kontan.co.id, 2019), and this was observed to be an $80.88 \%$ increase to the 320,506 investors reported by PT Kustodian Sentral Efek Indonesia (KSEI) in 2013 (Okezone.com, 2017). 
The number of companies placed on Indonesia Stock Exchange has increased quite significantly in proportion to the number of investors and this observed from the fact that there were 487 companies registered to have gone public starting from the establishment of IDX up to the end of December 2013 and the number rose to 677 companies in December 2019 showing a $39.01 \%$ increase (SahamOK.com, 2020).

According to Salvatore (2005) the placement of these companies in the stock exchange is mainly targeted towards increasing the prosperity of owners or investors through an increment in the firm value. Permatasari \& Azizah (2018) also showed an increase in firm value has a major influence on investors' investment decisions due to its ability to illustrate the financial condition and the level of risks being faced by a company.

One of the financial ratios usually used in describing firm value is the price to book value (Brigham \& Houston, 2012). Such that a higher PBV ratio means the company has succeeded in creating value for stockholders and also serves as a sign showing the market believes in the company's prospects (Warsono \& Zoebaedi, 2019).

Several previous studies have also used PBV as a proxy for firm value (Ahmadi, 2017; Cahyaningrum \& Antikasari, 2017; Khairiyani, 2018; Khairiyani et al., 2019; Mubyarto, 2019; Mubyarto \& Khairiyani, 2019; Ohlson, 2001; Shittu et al., 2016). The analysis of the PBV ratio allows investors to identify stocks with a reasonable price such as those attached to the actual condition of the company's fundamentals or financial performance as well as over-value or under-value prices (Eliza, 2013; Pascayanti et al., 2017).

The Indonesia Stock Exchange (IDX), as the capital market authority, releases several indexes for stock lists according to their characteristics in order to make it easier for investors to select preferred stocks. One of these lists is the LQ45 which contains a list of 45 selected stocks selected every 6 months based on certain criteria such high liquidity on the stock market, high market capitalization value, company's positive long-term fundamental performance, and having a great influence on the index's movement of Joint Stock Price (Hartono, 2017; Leiwakabessy, 2018; Pratama, 2019; Warsono \& Zoebaedi, 2019).

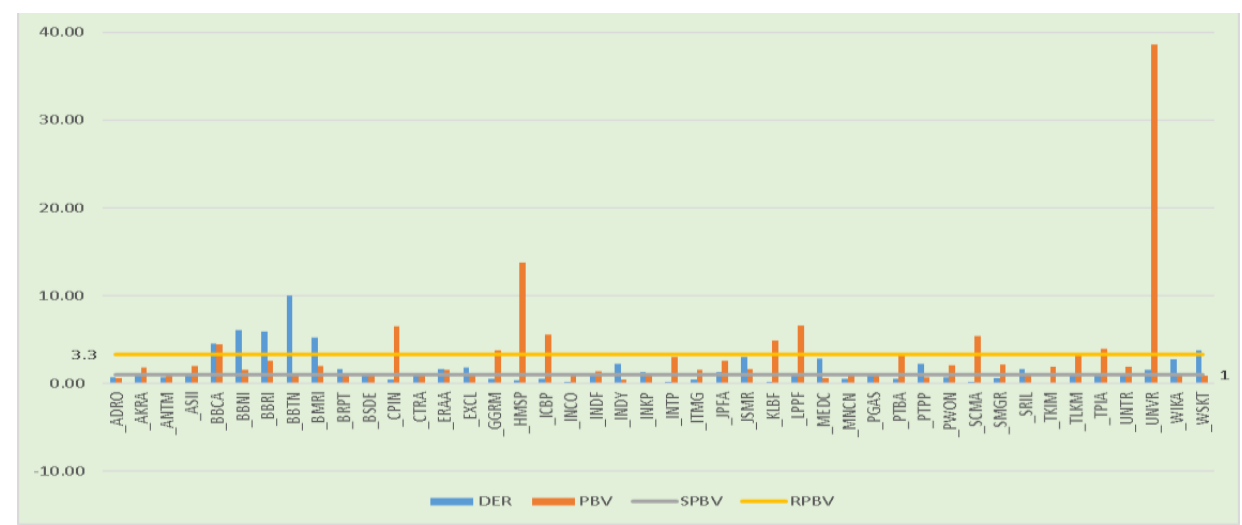

Source: $w w w . i d x . c o . i d$ processed data

Figure 1. Value of Price to Book Value (PBV) and Debt to Equity Ratio (DER) Per Company LQ45 December 2018 
Figure 1 shows the PBV value between companies is relatively variable and this means the market responds differently to the appreciation of the book value of a company's shares. Meanwhile, even though the stocks in the LQ45 index have high liquidity and large market capitalization supported by good fundamental performance, not all the companies have high firm value as observed from at least 11 companies with PBV values below one or considered under-valued. This factual phenomenon is not in line with the findings of Sugiono \& Untung (2019) that companies with good management are expected to have a PBV value of at least one or stay above the book value.

Firm value is influenced by several factors and one of these is profitability (Haugen \& Baker, 1996) such that greater profitability leads to more income to be distributed for shareholders and this is expected to increase the firm value (Yang et al., 2010). This was also reported by (Weston \& Copeland, 2008) that high profitability reflects the company's ability to generate high returns for shareholders and this means a better company's performance increases its value.

Return on Assets (ROA) is an indicator which is usable as a proxy for profitability (Keown et al., 2014). This is associated with the ability of its ratio to measure the capability of a company to generate net profit from its assets and also to evaluate its investment return. Several studies have shown the significant and positive effects of profitability on firm value (Chen \& Chen, 2011; López-Iturriaga \& Rodríguez-Sanz, 2001; Sabrin et al., 2016; Safitri et al., 2014; Sucuahi \& Cambarihan, 2016; Tui et al., 2017). While some others showed negative and significant effects (Purwohandoko, 2017). Meanwhile, Hirdinis (2019) reported there was no significant effect of profitability on firm value.

Therefore, the theory and results of previous studies as well as the logical thinking previously described led to the formulation of the first hypothesis for this study which is $\mathbf{H 1}$ : Profitability has a significant effect on firm value.

An observant investor does not only check a company's performance in generating net profit but also evaluates how much of its capital cost composition was used. It is, however, possible to determine the optimal funding composition as an effort to balance the finance owned and funds borrowed through the use of a capital structure analysis tool (Kewal, 2019).

According to Sudana (2011) a company's capital structure is closely related to longterm spending which is usually measured using the ratio of long-term debt to equity which is also known as leverage. Therefore, capital structure or leverage is used in this study and proxied by the Debt to Equity Ratio (DER) which is the ratio used in comparing debt and capital (Ang, 1997; Sugiono \& Untung, 2019). Leverage has been discovered to be important in maximizing firm value (Welley \& Untu, 2015).

The data obtained for the 2015-2018 period showed the average value of debt to equity ratio is 1.75 or greater than 1 and this means the financing structure of companies in the LQ45 index has more debt than capital. Meanwhile, Hanafi \& Halim (2018) reported that companies with total debt greater than total assets are not solvable.

The use of a smaller cost of capital from or by combining liability and equity to compile assets is better because it eases the company the burden of excessive capital costs 
(Sukamulja, 2017). Moreover, Hery (2019) showed companies are generally recommended to have a DER less than 0.5 based on the rule of debtors but this provision varies with the type of industry. A company is, however, stated by Sukamulja (2017) to be good in a situation its maximum liabilities are equal to its equity value such that DER is equal to 1 .

A greater market capitalization of a company means it needs more capital which is usually fulfilled by the management through debt policies and other external sources of financing (Hermuningsih, 2012). The addition of company debt also serves as a means for the management to control cash freely in order to control productivity and performance and subsequently strengthen the firm value which is reflected in the increase in stock market prices (Meidiawati \& Mildawati, 2016).

Several empirical studies on the relationship between capital structure and firm value have reported different results, for example, Chen \& Chen (2011) found leverage to generally have a very negative effect on firm value and the same finding was reported by (Ambarwati \& Stephanus, 2014; Dutta et al., 2018; Ernawati \& Widyawati, 2015; Rayan, 2008; Sujoko \& Soebiantoro, 2007; Zuhroh, 2019). In other studies, leverage was reported to have a significant positive impact on firm value (Anton, 2016; Cheng \& Tzeng, 2011; Putri \& Ukhriyawati, 2016). This means an increase in the portion of the debt in a company's capital structure has the ability to cause an increase in the firm value.

This theory and the results of previous research supported by logical and rational academic arguments led to the formulation of the second hypothesis, H2: Capital structure (leverage) has a significant effect on firm value.

Several capital structure theories have been used to explain the pattern of relationship between profitability, capital structure, and firm value such as Modigliani and Miller's capital structure, Agency, Pecking Order, Asymmetric Information or Signaling, and Tradeoff or Balancing Theories:

First, Modigliani \& Miller (1963) in "Corporate Income Taxes and The Cost of Capital: A Correction" proved there are benefits attached to using debt from tax savings due to the nature of tax-deductibility of interest payments. The interest on the debt is deducted in tax calculations and this leads to an increase in firm value in line with the increasing amount of debt with the value observed to be reaching a maximum point when it is entirely financed with debt.

Second, Agency Theory was proposed by Jensen \& Meckling (1976) and it states that it is possible to control the excessive use of free cash flow by management through the use of debt in order to avoid wasted investment. The use of debt also makes the management to be more careful due to its ability to increase the risk of bankruptcy (Jensen, 1986).

Moreover, the theory suggests a company's capital structure should contain a large portion of the debt which serves as a control mechanism against the tendency of managers to behave opportunistically. Therefore, the arguments from Jensen on the agency theory of capital structure shows the use of debt accompanied by prudence principle has the ability to increase firm value.

Third, the Pecking Order Theory explanation from (Myers \& Majluf, 1984) is contrary to the opinion of Modigliani \& Miller (1963) as well as Jensen (1986) agency theory on the 
importance of debt in the company's capital structure. It shows there is a problem of information asymmetry and interpretations between investors on the company's financing policies through debt and issuing new equity as bad news. According to Myers (1984) a profitable company with high profit has abundant internal funding sources and this leads to having a low debt level. This, therefore, means there is no optimal capital structure in the pecking order theory (Smart et al., 2004).

Fourth, Asymmetric Information and Signaling Theory is also in contrast to the pecking order theory which tends to avoid using debt as the main instrument of company's capital structure, as well as the agency theory of Jensen (1986) which sees the need for debt from the aspect of agency conflict resolution, and Modigliani \& Miller theory (1963) which supports the use of debt from aspects of tax-deductibility of interest payment. This theory tries to explain the company's capital structure or leverage from the aspect of asymmetric information availability which shows the existence of different information for different parties regarding the company's prospects and risks in a real market.

The lack of information by external parties leads to the tendency to protect themselves by offering the company low prices. Therefore, companies need to minimize information asymmetry as an effort to increase the firm value for both investors and creditors (Filbeck, 2011).

Signal theory involves publishing periodic financial reports which are the most important part of a company's fundamental analysis to ensure accessibility by external parties. The information reflecting the increase in company profitability which is reflected in the value of Return on Assets (ROA) is a good signal for investors. A high ROA value indicates good financial performance and this means investors will be interested in investing their funds through securities or stocks. Meanwhile, from the capital structure aspect which is added to the new debt or financial leverage, signaling theory provides information to show the company can be trusted by the creditor while the issuance of new shares shows the need for funding (Rodoni \& Ali, 2014).

Fifth, there is a conflict between the theories or the existence of theoretical gaps to explain the best capital structure and this led to the development of a more moderate concept which is known as the Trade-off Theory. It explains how a company determines the most optimal composition between equity and external capital in its capital structure (Myers \& Majluf, 1984). Trade-off theory is also often called Balancing Theory and discusses the relationship between the capital structure and firm value associated with taxes, risk of bankruptcy and the portion of debt usage caused by the decisions taken by the company (Brealey et al., 2011).

According to this theory, it is possible to achieve the optimal capital structure by balancing the benefits of tax savings and bankruptcy costs for the use of debt. In case leverage is used by the company, the benefit is in the form of tax savings or tax shield. However, the costs of using leverage such as bankruptcy and agency costs also need to be considered in an imperfect capital market (Keown et al., 2014).

Panno (2003) found the evidence companies in a well-developed or marketable financial market tend to make adjustments to achieve optimal capital structure or leverage. 
Meanwhile, companies facing an inefficient financial market prioritize equity issuance over pursuing optimal leverage ratios.

The relationship between profitability, capital structure, and firm value has been empirically studied by Chen \& Chen (2011) and the results showed profitability affects firm value directly and indirectly through the use of capital structure as a mediator. The same result was also reported by (Hermuningsih, 2012; Thaib \& Dewantoro, 2017; Zuhroh, 2019).

These findings supported by logical thinking led to the formulation of the third hypothesis, H3: Profitability significantly affects firm value through the use of capital structure as a mediating or intervening variable.

The novelty of this research includes (i) previous research partly only tested the direct effect of independent variable on the dependent variable using ordinary linear regression method, while a mediating or intervening variable was used in this study, (ii) a previous study used a structural equation model (SEM) analysis to evaluate the direct and indirect effects but this model has been observed by researchers to have a weakness which involves the standardization of the coefficient values (Beta) produced which makes it impossible to reinterpret the numbers, (iii) this study uses a panel data structure which allows the researcher to present many observations with a limited number of time series and this is considered useful to avoid analysis bias due to limited number of observations, (iv) a path analysis method including Sobel Test and Bootstrapping techniques through the help of Statistical Product and Service Solutions (SPSS) Software combined with Hayesmacros Software was used in this study. This, therefore, makes the calculation of direct and indirect effects and the determination of significance level or probability possible which are unable to be generated automatically using the ordinary regression method assisted by the SPSS program.

The four main contributions of this study include theoretical, empirical, methodological, and practical. It is theoretically expected to contribute to the study of capital structure theories including Modigliani and Miller, Agency, Pecking Order, Asymmetric Information or Signaling, and Trade-off or Balancing theory towards understanding the existing phenomena partially and comprehensively relating to the research variables.

Furthermore, the study is empirically expected to provide solutions to research problems directly in the field, additional insights, and information for academics, and to serve as reference material for further research. The methodological contribution involves determining the best method to obtain the right answers or solution to a particular problem while the practical aspects are expected to provide input and consideration for company's leadership to ensure effective and efficient management of assets and debt composition in the capital structure as well as the risks inherent in these policies due to its further effect on firm value.

In line with the phenomena, theoretical basis, support for empirical studies, as well as the terminology of the path analysis model, 5 problems were developed to be answered in this research and they include (I) How does total profitability affect firm value? (II) Does 
profitability have a direct effect on capital structure? (III) Does capital structure have a direct effect on firm value by controlling the profitability variable? (IV) Does profitability have a direct effect on firm value when controlled by capital structure? (V) What is the effect of profitability on firm value through the use of capital structure as a mediating or intervening variable?

\section{METHOD}

This study was conducted with quantitative analysis methods using secondary data. It is an explanatory research conducted to test the hypothesis developed through a particular theory to justify or strengthen the hypothesis and develop theories and hypotheses though several existing research results. This study focused on predicting and analyzing the direct and indirect effect of profitability on firm value through the use of capital structure as a mediating or intervening variable.

The population of this study were 45 companies listed in the LQ45 index and obtained from the financial reports of Indonesia Stock Exchange (IDX) as of August 2019 and the 44 samples used were selected using the purposive sampling method with certain considerations such as being listing based on financial statements as at December 31st and have complete financial reports for the 2015-2018 period.

Data were analyzed using the Path Analysis Method through the Sobel Test and Bootstrapping Techniques on Statistical Product and Service Solutions (SPSS) Software version 22 combined with Hayesmacros Software (Ghozali, 2013). This is in line with the Conceptual Framework developed by Chen \& Chen (2011) that profitability affects firm value directly and indirectly through the use of capital structure as a mediator or an intervening variable (Figure 2).

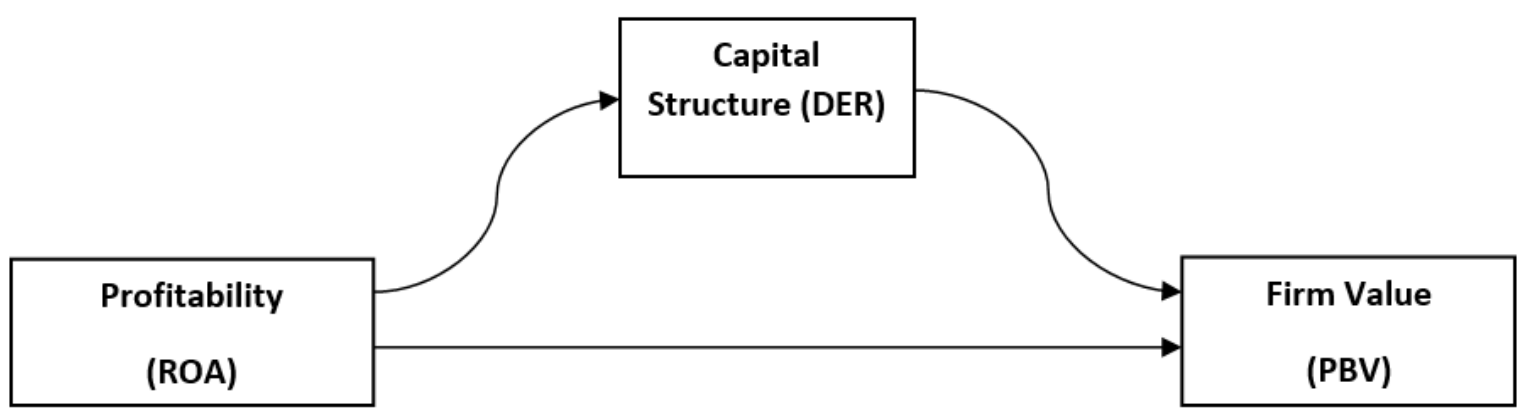

Figure 2. Research Framework for "The analysis of mediating factors"(Chen \& Chen, 2011).

The panel data structure used in this study includes the variables for each company such as Price to Book value (PBV) as a proxy for firm value, Return on assets (ROA) as a proxy for profitability, and Debt to Equity ratio (DER) as a proxy for capital structure (leverage). The path analysis equation method used is:

$$
\begin{aligned}
& P B V_{i t}=\alpha+\beta_{1} R O A_{i t}+\varepsilon \ldots \ldots \ldots \ldots \ldots \\
& D E R_{i t}=\alpha+\beta_{2} R O A_{i t}+\varepsilon \ldots \ldots \ldots \ldots \ldots \\
& P B V_{i t}=\alpha+\beta_{3} R O A_{i t}+\beta_{4} D E R_{i t}+\varepsilon
\end{aligned}
$$


Description: $\alpha$ is a constant (intercept), $\beta$ is the coefficient (slope), $i$ is unit cross, $t$ is time, and $\varepsilon$ is the error term.

\section{FINDING AND DISCUSSION}

The estimation results from the analysis are presented in Table 1.

Table 1. Estimation Result of the Direct Effect and Total Effect Profitability on Capital Structure and Firm Value.

\begin{tabular}{lllll}
\hline & Coeff & s.e. & $t$ & Sig(two) \\
\hline $\mathrm{b}($ YX) & .7529 & .0517 & 14.5573 & .0000 \\
$\mathrm{~b}(\mathrm{MX})$ & -.0595 & .0154 & -3.8589 & .0002 \\
$\mathrm{~b}(\mathrm{YM} . \mathrm{X})$ & 1.0534 & .2423 & 4.3472 & .0000 \\
$\mathrm{~b}(\mathrm{YX} . \mathrm{M})$ & .8155 & .0513 & 15.8933 & .0000 \\
\hline
\end{tabular}

\section{The Effect of Total Profitability (ROA) on Firm Value (PBV).}

The coefficient value $b$ for (YX) is 0.7529 at a significance of 0.0000 which is $<$ alpha 0.05 and this shows total profitability has a positive and significant influence on the firm. This means every 1 percent increase in profitability produces a 0.73 percent increase in total firm value and this indicates companies on the LQ45 index are averagely profitable and further have a positive effect on firm value.

It also shows the companies are able to manage their assets to generate a higher profit level and this is in line with the provisions of the signaling theory that the information provided to show the increase in a company's profitability and reflected in the value of Return on Assets (ROA) is a good signal for investors. Moreover, increasing positive ROA values indicates the company's financial performance is good and this encourages investors to invest their funds through securities and stocks.

According to Sujoko \& Soebiantoro (2007) high opportunity indicates good prospects for a company, and investors respond positively to these signals, thereby, leading to an increase in the firm value. These results are supported by the findings of previous studies (Chen \& Chen, 2011; Haugen \& Baker, 1996; López-Iturriaga \& Rodríguez-Sanz, 2001; Sabrin et al., 2016; Safitri et al., 2014; Sucuahi \& Cambarihan, 2016; Tui et al., 2017; Weston \& Copeland, 2008; Yang et al., 2010) that a greater company's profitability makes more revenue available to be distributed to shareholders and for business expansion and this is expected to provide a higher firm value.

\section{Direct Effect of Profitability (ROA) on Capital Structure (DER).}

One of the factors affecting debt policy is profitability due to its ability to reflect the return on investment. The estimation results, however, showed the $b$ coefficient (MX) value is -.0595 at a significance of 0.0002 which is < alpha 0.05 and this proves there is a negative and significant direct effect of profitability on the capital structure for LQ45 companies during the study period. This means an increase in profitability (ROA) by $1 \%$ reduces the 
portion of debt incurred by the company by $0.06 \%$. Therefore, the generation of more profit by a company is expected to reduce the portion of the debt in its capital structure.

These findings show the company's capital structure policy did not lead to an optimal capital structure or leverage for the period studied and this is in agreement with Myers (1984) pecking order theory which states that companies with high levels of profitability actually have low debt levels due to the availability of abundant internal sources of funds.

The theory shows retained earnings are the main choice for funding followed by debt or equity and this further proves the less likeliness of using debt when there is more profit, especially with internal equity derived from retained earnings.

Therefore, companies in the LQ45 index were observed to averagely tend to formulate policies to reduce the composition of debt in the capital structure in line with an increase in profitability during the study period. They mostly geared their efforts towards utilizing the internal sources of funding such as retained earnings for business expansion.

\section{Direct Influence of Capital Structure on Firm Value when controlled by Profitability Variable.}

The $b$ coefficient (YM.X) value was found to be 1.0534 at a significance of 0.0000 and this proves the direct effect of capital structure (DER) on firm value (PBV) is positive and significant when controlled by variable profitability (ROA). This means an increase in the amount of debt by $1 \%$ leads to an increment in the firm value by $1.05 \%$ and this further indicates capital structure or leverage coefficient value is higher as observed with 1.05 when controlled by profitability. The company's management policy was observed to have the tendency of making adjustments to ensure a positive response from the optimal capital structure or leverage by the market.

It is, however, important to remember that the positive response of firm value to an increase in the debt portion of a company's capital structure is inseparable from the profitability level control. Therefore, the policies leading to optimal capital structure or leverage are justified in line with the trade-off theory from Myers \& Majluf (1984) based on the conditions of well-developed or marketable financial markets or profitability of the company.

This finding is supported by several previous empirical studies including (Anton, 2016; Cheng \& Tzeng, 2011; Putri \& Ukhriyawati, 2016) which also found a positive and significant effect of leverage on firm value. Meanwhile, additional debt also functions as a tool to freely control cash by the management in certain conditions and this further shows the important role of leverage in maximizing firm value (Welley \& Untu, 2015). An increase in the control of funds leads to an increment in the productivity and performance of a company and this also strengthens the firm value through an increase in stock market prices (Meidiawati \& Mildawati, 2016).

Direct Effect of Profitability on Firm Value using Capital Structure as a Controlling Variable. 
The $b$ coefficient (YX.M) value was found to be 0.8155 at a significance of 0.0000 and this proves profitability has a significant effect on firm value when controlled by the capital structure. This means every $1 \%$ increase in profitability leads to an increment in the firm value by $0.82 \%$ and reflects the ability of a company to generate fixed profits is a necessary condition to increase firm value. Meanwhile, the debt portion is also very much needed, as a sufficiency condition, to strengthen the relationship between profit and firm value.

The 0.82 value is smaller than the 1.05 obtained for the direct influence of capital structure on firm value when controlled by the profitability variable and this shows the positive effect of capital structure is directly greater than the effect of profitability on firm value. Therefore, a good company financial management control over the capital structure is expected to increase company profitability and provide a good impact on improving the firm value.

This finding is in line with the signaling theory which states that the information on the increase in profitability of a company as indicated by the Return on Assets (ROA) is a good signal for investors. Meanwhile, from the capital structure aspect, adding new debt or financial leverage provides creates an avenue of trust in the company by the creditor based on signaling theory. These findings also indicate the two aspects of policy which are the company's ability to generate profitability and corporate debt management, need to be complementary.

These results are in agreement with the findings of (Chen \& Chen, 2011; Haugen \& Baker, 1996; López-Iturriaga \& Rodríguez-Sanz, 2001; Sabrin et al., 2016; Safitri et al., 2014; Sucuahi \& Cambarihan, 2016; Tui et al., 2017; Weston \& Copeland, 2008) that greater profitability leads to more income to be distributed among shareholders and for business expansion and this subsequently increases the firm value. It also shows the company's ability to manage assets effectively to produce a higher profit level.

\section{Indirect Effect of Profitability on Firm Value Using Capital Structure as a Mediator or Intervening variable.}

Path analysis method with Sobel significance test and Bootstrapping was used to determine the indirect effect of profitability on firm value through the use of capital structure as a mediator and the estimation results are as follows:

Table 2. Estimation Results of Path Analysis Using Sobel Test

\begin{tabular}{lllllll}
\hline & Value & s.e. & LL 95 CI & UL 95 CI & Z & Sig(two) \\
\hline Effect & -.0626 & .0220 & -.1058 & -.0195 & -28441 & .0045 \\
\hline
\end{tabular}

Table 2 shows the path analysis coefficient value is -0.0626 at a significance of 0.0045 which is < alpha 0.05 and this proves the indirect effect of profitability on firm value using capital structure as a mediator is negative and significant based on the Sobel test. 
Jurnal Economia, 16(2), October 2020, 184-199

\begin{tabular}{llllllll}
\hline & Data & Mean & s.e & LL 95 CI & UL 95 CI & LL 99 CI & UL 99 CI \\
\hline Effect & -.0626 & -.0616 & .0157 & -.0972 & -.0360 & -.1082 & -.0285 \\
\hline
\end{tabular}

The significance test conducted using Bootstrapping shows the $z$-count value is Mean/se or $-0.0616 / 0.0157=-3.99$ which is $>$ the $95 \%$ Confidence Interval value and $Z=$ \pm 1.96 . It is important to note that the $z$-value marked \pm is ignored. This means the indirect effect of profitability on firm value through the use of capital structure as a mediator is also negative and significant.

The results showed there has been a change in the pattern of relationship between profitability and firm value as observed from the initial positive effect from the direct estimation presented in Table 1 and the negative effect due to the mediation by the capital structure. This, therefore, shows management's policy to reduce the portion of the debt in capital structure due to the increase in company profitability leads to a negative response from the market.

The policy implemented is in line with Myers (1984) pecking order theory which stated that a greater profit leads to less likelihood of using debt in capital structure due to the availability of internal equity from retained earnings.

Meanwhile, the policy contradicts the results reported by Panno (2003) that companies in a well-developed or marketable financial market tend to adjust towards an optimal capital structure or leverage while those facing an inefficient financial market prioritize equity issuance over the pursuance of optimal leverage ratios.

\section{CONCLUSION}

The findings of this research showed increased profitability is directly able to increase firm value and the same was found for debt which also has a positive direct effect. Meanwhile, the policy implemented by the company's management to reduce the portion of the debt in the capital structure to increase profitability was observed to have decreased the benefits of the debt, thereby, making the pattern of relationship between profitability and firm value to be negative. This is associated with the greater negative impact of reducing the portion of the debt on capital structure compared to the positive impact obtained from increased profitability on firm value. This means the market is more sensitive to the policy focused on decreasing the debt portion than the positive response generated by the company's success in creating profits.

The company's capital structure policy which does not lead to an optimal capital structure was found to be less precise. Therefore, it is recommended that the company's ability to generate profits should be continually increased as a necessary condition to increase firm value due to the possibility of increasing earnings per share through high profit and subsequently project a better company's image to investors.

Moreover, a good managerial ability to determine the proportion of debt in the optimal capital structure of a company is a sufficient condition to maintain a positive relationship between profitability and firm value. This means the ability of a company to generate greater profits from the investment financed by debt than the interest rate liabilities 
lead to an increment in its profit level due to the use of debt, even though risks are also increased.

According to the trade-off or balancing theory, designing an optimal capital structure is crucial to the efforts towards increasing firm value. It is very important to determine the best composition between own and debt capitals due to the effects of the amount of composition (mix) for each capital on the profitability and liquidity of the company and its subsequent influence on the firm value.

This means debt does not always have a negative connotation as long as the goal is productive and this is known as the good debt. A professional management of productive debt has the ability to create financial leverage to make the company enjoy greater profits in the future.

There is also the need for company management to continuously publish financial performance reports in line with the signal or asymmetric information theory which states that policies directed towards the continuous provision of information on company's financial performance and profitability through the return on assets value is a good signal for investors and has a further positive impact on firm value.

Meanwhile, from the aspect of capital structure, the addition of new debt based on signaling theory also provides information required by creditors to trust the company and this also subsequently has a positive impact on firm value.

\section{REFERENCES}

Ahmadi, A. (2017). The Stock Price Valuation of Earnings Per Share and Book Value: Evidence From Tunisian Firms. The Journal of Internet Banking and Commerce, 22(1), 111.

Ambarwati, I. E., \& Stephanus, D. S. (2014). Struktur Kepemilikan, Kebijakan Dividen, dan Leverage sebagai Determinan atas Nilai Perusahaan. Jurnal Akuntansi Multiparadigma, 170-184.

Ang, R. (1997). Buku pintar pasar modal Indonesia (the intellegent guide to Indonesian capital market). Jakarta: Mediasoft Indonesia.

Anton, S. G. (2016). The Impact of Dividend Policy on Firm Value. A Panel Data Analysis of Romanian Listed Firms. Journal of Public Administration, Finance and Law, 10, 107112.

Brealey, R. A., Myers, S. C., \& Allen, F. (2011). Principles of corporate finance (10th ed). New York: McGraw-Hill/Irwin.

Brigham, E. F., \& Houston, J. F. (2012). Fundamentals of Financial Management (Concise Edition). Cengage Learning.

Cahyaningrum, Y. W., \& Antikasari, T. W. (2017). The Influence of Earning Per Share, Price to Book Value, Return on Asset, and Return on Equity to Stock Price in Finance Company. Jurnal Economia, 13(2), 191-200. https://doi.org/10.21831/economia.v13i2.13961 
Chen, L.-J., \& Chen, S.-Y. (2011). The Influence of Profitability on Firm Value with Capital Structure as the Mediator and Firm Size and Industry as Moderators". Investment Management and Financial Innovations, Vol. 8, Issue 3, pp. 121-129.

Cheng, M.-C., \& Tzeng, Z.-C. (2011). The Effect of Leverage on Firm Value and How The Firm Financial Quality Influence on This Effect. World Journal of Management, 3, 3053.

Dutta, S. R., Mukherjee, T., \& Sen, S. S. (2018). Impact of Financial Leverage on the Value of Firm: Evidence from Some NSE Listed Companies. 4, 42-52.

Eliza, E. (2013). Hubungan Nilai Intrinsik Suatu Saham Terhadap Harga Pasar Saham Tersebut. Jurnal Ekonomi : Journal of Economic, 4(1), Article 1.

Ernawati, D., \& Widyawati, D. (2015). Pengaruh Profitabilitas, Leverage dan Ukuran Terhadap Nilai Perusahaan. Jurnal Ilmu Dan Riset Akuntansi, Vol 4(No 4), 1-19.

Filbeck, G. (2011). Asymmetric Information and Signaling Theory. In Dividends and Dividend Policy (pp. 163-177). John Wiley \& Sons, Ltd. https://doi.org/10.1002/9781118258408.ch10

Ghozali, I. (2013). Aplikasi Analisis Multivariate dengan Program IBM SPSS 21 Update PLS Regresi (Semarang; Edisi 7). Semarang: Undip.

Hanafi, M., \& Halim, A. (2018). Analisis Laporan Keuangan (Edisi Kelima). Yogyakarta: UPP STIM YKPN.

Hartono, J. (2017). Teori Portofolio Dan Analisis Investasi (Edisi 11). Yogyakarta: BPFE.

Haruman, T. (2008). Pengaruh Struktur Kepemilikan Terhadap Keputusan Keuangan dan Nilai Perusahaan. 29.

Haugen, R. A., \& Baker, N. L. (1996). Commonality in the determinants of expected stock returns. Journal of Financial Economics, 41(3), 401-439. https://doi.org/10.1016/0304405X(95)00868-F

Hermuningsih, S. (2012). Pengaruh Profitabilitas, Size Terhadap Nilai Perusahaan dengan Struktur Modal Sebagai Variabel Intervening. Jurnal Siasat Bisnis, 16(2), Article 2.

Hery. (2019). Analisis Laporan Keuangan: IIntegrated and Comprehensive Edition. Jakarta: Grasindo.

Hirdinis, M. (2019). Capital Structure and Firm Size on Firm Value Moderated by Profitability. International Journal of Economics \& Business Administration (IJEBA), VII(1), 174-191.

Jensen, M. (1986). Agency Costs of Free Cash Flow, Corporate Finance, and Takeovers. American Economic Review, 76(2), 323-329.

Jensen, M. C., \& Meckling, W. H. (1976). Theory of the firm: Managerial behavior, agency costs and ownership structure. Joumal of Financial Economics, 3(4), 305-360. https://doi.org/10.1016/0304-405X(76)90026-X

Keown, A. J., Martin, J. D., \& Petty, J. W. (2014). Foundations of finance: The logic and practice of financial management (8th ed). Boston: Pearson. 
Kewal, S. S. (2019). Optimum Capital Structure Adjustment Speed on Companies Listed in Indonesia Stock Exchange. Jurnal Economia, 15(1), 60-68. https://doi.org/10.21831/economia.v15i1.23226

Khairiyani, K. (2018). Bagaimana Tata Kelola Internal Perusahan Pertambangan? Jurnal Akuntansi Multiparadigma, 9(2), 365376.https://doi.org/10.18202/jamal.2018.04.9022

Khairiyani, K., Mubyarto, N., Mutia, A., Zahara, A. E., \& Habibah, G. W. I. A. (2019). Kinerja Lingkungan Terhadap Kinerja Keuangan Serta Implikasinya Terhadap Nilai Perusahaan. ILTIZAM Journal of Shariah Economic Research, 3(1), 41-62. https://doi.org/10.30631/iltizam.v3i1.248

Kontan.co.id. (2019). https://investasi.kontan.co.id/news/jumlah-investor-baru-di-pasarmodal-indonesia-bertambah-57234-di-januari-2019.

Leiwakabessy, P. (2018). Analisis Komparasi Risiko Saham LQ 45 dan Non LQ 45 Pada Beberapa Sub Sektor Perusahaan Yang Terdaftar Di Bursa Efek Indonesia (BEI). Ekonomi \& Bisnis, 17(2), 80-91. https://doi.org/10.32722/eb.v17i2.1404

López-Iturriaga, F. J., \& Rodríguez-Sanz, J. A. (2001). Ownership Structure, Corporate Value and Firm Investment: A Simultaneous Equations Analysis of Spanish Companies. Journal of Management and Governance, 5(2), 179-204. https://doi.org/10.1023/A:1013078225905

Meidiawati, K., \& Mildawati, T. (2016). Pengaruh Size, Growth, Profitabilitas, Struktur Modal, Kebijakan Dividen Terhadap Nilai Perusahaan. Jurnal Ilmu Dan Riset Akuntansi (JIRA), 5(2), 1-16.

Modigliani, F., \& Miller, M. H. (1963). Corporate Income Taxes and the Cost of Capital: A Correction. The American Economic Review, 53(3), 433-443.

Mubyarto, N. (2019). Profitabilitas, Ukuran Perusahaan, Leverage, dan Kebijakan Deviden Sebagai Determinan Atas Nilai perusahaan. ILTIZAM Journal of Shariah Economic Research, 3(2), 1-29. https://doi.org/10.30631/iltizam.v3i2.506

Mubyarto, N., \& Khairiyani, K. (2019). Kebijakan Investasi, Pendanaan, dan Dividen Sebagai Determinan Nilai Perusahaan. Jurnal Akuntansi Multiparadigma, 10(2).

Myers, S. C. (1984). The Capital Structure Puzzle. Journal of Finance, 39(3), 575-592.

Myers, S. C., \& Majluf, N. S. (1984). Corporate financing and investment decisions when firms have information that investors do not have. Journal of Financial Economics, 13(2), 187-221. https://doi.org/10.1016/0304-405X(84)90023-0

Ohlson, J. A. (2001). Earnings, Book Values, and Dividends in Equity Valuation: An Empirical Perspective*. Contemporary Accounting Research, 18(1), 107-120. https://doi.org/10.1506/7TPJ-RXQN-TQC7-FFAE

Okezone.com.(2017).https://economy.okezone.com/.https://economy.okezone.com/read /2017/12/27/278/1836423/ksei-catat-jumlah-nvestor-ritel-1-1-juta-naik-25-24didominasi-anak-zaman-now

Panno, A. (2003). An empirical investigation on the determinants of capital structure: The UK and Italian experience. Applied Financial Economics, 13(2), 97-112. https://doi.org/10.1080/09603100210100882 
Pascayanti, Y., Rahman, A. F., \& Andayani, W. (2017). Relevansi Nilai Atas Nilai Wajar Aset dan Liabilitas Dengan Mekanisme Good Corporate Governance Sebagai Variabel Pemoderasi. InFestasi, 13(1), 227-242. https://doi.org/10.21107/infestasi.v13i1.3045

Permatasari, D., \& Azizah, D. F. (2018). Pengaruh Struktur Modal Terhadap Nilai Perusahaan (Studi Pada Perusahaan Sub Sektor Makanan Dan Minuman Yang Terdaftar Di Bursa Efek Indonesia Tahun 2013-2016). Jurnal Administrasi Bisnis, 61(4), 100-106.

Pratama, L. (2019). Analisis Pembentukan Portofolio Saham Optimal Menggunakan Metode Single Index Model (Studi Empiris pada Saham Indeks LQ 45 di Bursa Efek Indonesia). Jurnal Ilmu Manajemen, 16(1), 48-60. https://doi.org/10.21831/jim.v16i1.25064

Purwohandoko. (2017). The Influence of Firm's Size, Growth, and Profitability on Firm Value with Capital Structure as the Mediator: A Study on the Agricultural Firms Listed in the Indonesian Stock Exchange. International Journal of Economics and Finance, 9(8), p103. https://doi.org/10.5539/ijef.v9n8p103

Putri, R. W., \& Ukhriyawati, C. F. (2016). Pengaruh Likuiditas, Leverage dan Profitabilitas Terhadap Nilai Perusahaan Telekomunikasi yang Terdaftar di Bursa Efek Indonesia Tahun 2012-2014. BENING, 3(1), Article 1. https://doi.org/10.33373/bening.v3i1.920

Rayan, K. (2008). Financial leverage and firm value [Dissertation, University of Pretoria]. https://doi.org/10/78/ag

Rodoni, A., \& Ali, H. (2014). Manajemen Keuangan Modern. Jakarta: Mitra Wacana Media.

Sabrin, Sarita, B., Sujono, \& Syaifuddin, D. T. (2016). The Effect of Profitability on Firm Value in Manufacturing Company at Indonesia Stock Exchange. International Journal of Engineering Science, 5, 81-89.

Safitri, O. N., Handayani, S. R., \& Nuzula, N. F. (2014). The Influence of Capital Structure and Profitability on Firm Value (A Study in Retail Companies Listed in Indonesia Stock Exchange 2010-2013 period). Jurnal Administrasi Bisnis, 13(2), Article 2.

SahamOK.com. (2020). SahamOK.com. https://www.sahamok.com/

Salvatore, D. (2005). Ekonomi Manajerial dalam Perekonomian Global (Edisi 5). Jakarta: Salemba Empat.

Shittu, I., Che Ahmad, A., \& Ishak, Z. (2016). Price to Book Value, Price to Sales Multiples and Stock Price; Evidence from Nigerian Listed Firms. Journal of Advanced Research in Business and Management Studies, 3, 85-93.

Smart, S. B., Megginson, W. L., \& Gitman, L. J. (2004). Corporate Finance. South-Western: Thomson.

Sucuahi, W., \& Cambarihan, J. M. (2016). Influence of Profitability to the Firm Value of Diversified Companies in the Philippines. Accounting and Finance Research, 5(2), 149. https://doi.org/10.5430/afr.v5n2p149

Sudana, I. M. (2011). Manajemen keuangan perusahaan: Teori \& praktik (Edisi 2). Jakarta: Erlangga. 
Sugiono, A., \& Untung, E. (2019). Panduan Praktis Dasar Analisa Laporan Keuangan. Jakarta: PT Grasindo.

Sujoko, \& Soebiantoro, U. (2007). Pengaruh Struktur Kepemilikan Saham Leverage Faktor Intern Dan Faktor Ekstern Terhadap Nilai Perusahaan (Studi empirik pada perusahaan manufaktur dan non manufaktur di Bursa Efek Jakarta). Jurnal Manajemen Dan Kewirausahaan (Journal of Management and Entrepreneurship), 9(1), 41-48. https://doi.org/10.9744/jmk.9.1.pp. 41-48

Sukamulja, S. (2017). Pengantar Pemodelan Keuangan Dan Analisis Pasar Modal. Yogyakarta: Andi.

Thaib, I., \& Dewantoro, A. (2017). Pengaruh Profitabilitas dan Likuiditas Terhadap Nilai Perusahaan dengan Struktur Modal sebagai Variabel Intervening. Jurnal Riset Perbankan Manajemen Dan Akuntansi, 1(1), 25-44.

Tui, S., Nurnajamuddin, M., Sufri, M., \& Nirwana, A. (2017). Determinants of Profitability and Firm Value: Evidence from Indonesian Banks. IRA-International Journal of Management \& Social Sciences (ISSN 2455-2267), $7, \quad 84$. https://doi.org/10.21013/jmss.v7.n1.p10

Warsono, \& Zoebaedi, F. (2019). Determinan Nilai Perusahaan Dengan Struktur Modal Sebagai Variabel Intervening pada Perusahaan LQ 45 Di Indonesia. JRB-Jurnal Riset Bisnis, 3(1), 37-53. https://doi.org/10.35592/jrb.v3i1.979

Welley, M., \& Untu, V. (2015). Faktor-Faktor yang Mempengaruhi Nilai Perusahaan di Sektor Pertanian pada Bursa Efek Indonesia Tahun 2010-2013. Jurnal EMBA: Jurnal Riset Ekonomi, Manajemen, Bisnis Dan Akuntansi, 3(1), 972-983. https://doi.org/10.35794/emba.v3i1.7802

Weston, J. F., \& Copeland, T., E. (2008). Manajemen Keuangan (Jilid 2). Jakarta: Binarupa Aksara.

Yang, C.-C., Lee, C., Gu, A., \& Lee, Y.-W. (2010). Co-determination of capital structure and stock returns--A LISREL approach: An empirical test of Taiwan stock markets. The Quarterly Review of Economics and Finance, 50, 222-233. https://doi.org/10.1016/j.qref.2009.12.001

Zuhroh, I. (2019). The Effects of Liquidity, Firm Size, and Profitability on the Firm Value with Mediating Leverage. KnE Social Sciences, 203-230. 